\title{
TRADE LIBERALISATION IN SADC AND THE ECONOMIC BENEFITS OF BELONGING TO AN RTA: THE CASE OF TANZANIA
}

\author{
Nzeyimana Dyegula \\ Planning and Investment Manager, Rail Asset Holding Company, Tanzania \\ djesca@yahoo.com \\ Francis Lwesya \\ Department of Business Administration, School of Business Studies and Economics, University \\ of Dodoma, Tanzania \\ flwesya@yahoo.com.
}

\begin{abstract}
This paper examines the dynamics of trade liberalization in the Southern Africa Development Community $(S A D C)$ region and the economic benefits that Tanzania derives from SADC membership. We use qualitative analysis and trade indices. The findings show that SADC is far behind its agreed schedule of transforming the region into a customs union and SADC intraregional trade is very low, only South Africa and Mozambique show the potentials to increase intra-regional trade and benefit more from SADC in the short run. On the other hand, Tanzania's economic benefits from SADC membership have remained trivial, though her exports and market share have been steadily increasing since the mid-1990s. However, Tanzania does not suffer adversely from the dual memberships of EAC and SADC regions, despite its membership in the two overlapping RTAs making its trade regime complex because tariff reductions under EAC customs union are not compatible with SADC's, hence resulting in problems in implementing the SADC Trade Protocol. Nonetheless, the country may not need to withdraw its membership from either EAC or SADC due to signs of good prospects in the long run under the proposed harmonization of the EAC and SADC trade regime through the Tripartite Free Trade Area arrangement (COMESA-EAC-SADC).
\end{abstract}

\section{Keywords}

Trade Liberalization; Trade Integration; Trade intensity Index; Revealed Comparative Advantage Index (RCA); Regional Trade Area (RTA)

\section{JEL Classification}

F13; F1

\section{Introduction}

Regional integration in Africa particularly in Sub-Saharan Africa (SSA) has a long history since the formation of the Southern African Customs Union (SACU) in 1910. Currently, SSA contains 12 of the at least 14 regional trade agreements (RTAs) existing in Africa (see Figure 1 for some of the RTAs in SSA). Of the 14 RTAs eight of these are officially recognised by the African Union (AU) and they include: the Arab Maghreb Union (UMA), Common Market for Eastern and Southern Africa (COMESA), Community of Sahel-Saharan States (CEN SAD), East African Community (EAC), Economic Community of Central African States (ECCAS), Economic Community of West African States (ECOWAS), Inter-Governmental Authority on Development (IGAD), and the Southern Africa Development Community (SADC). While the remaining six RTAs are considered as inter-governmental agencies and these are: Central African Economic Community (CEMAC), Economic 
Community of Great Lakes Countries (CEPGL), Indian Ocean Commission (IOC), Mano River Union (MRU), SACU and West Africa Economic and Monetary Union (WAEMU).

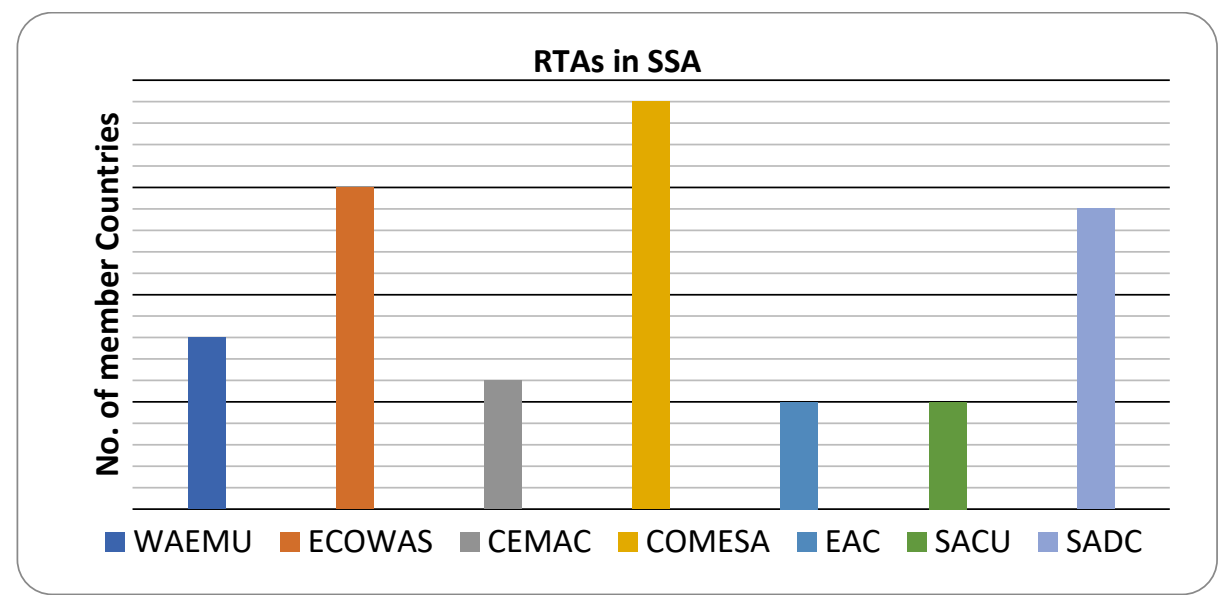

Figure 1 Selected RTAs in Sub-Saharan Africa

Regional integration has been going on along with the development of intra trade agreements with the implementation of SADC being the most recent (Meyer et al. 2010). With at least 12 RTAs, most countries in SSA belong to at least two of them, thus regional integration in the sub-region is very complex and confusing affair, what Alves et al. (2007) describe as "a spaghetti bowl that hinders regional integration by creating a complex entanglement of political commitments and institutional requirements." With Tanzania being a member of EAC and SADC, this is similar to many SSA countries that have multiple memberships in various RTAs. As a result, some regional trade groupings such as SADC have had to refocus their agendas and strategies (e.g. SADC's original commitment to the introduction of a customs union in 2010) while others such as COMESA are deepening their trade integration (e.g. COMESA FTA implementing its Customs Union in 2010).

RTAs have different objectives and these range from purely market or economic integration to socio-political cooperation agreements. The motives for Tanzania to become a member of SADC (SADCC then), however, were for socio-political cooperation such as the fight against Apartheid policies in South Africa amongst others. In all cases Tanzania has been a committed member in advocating the fraternity objective of SADC states. Tanzania withdrew its membership from COMESA in 2000 because the government perceived less beneficial compared with EAC and SADC, and believed that the agendas of these organizations were incompatible with COMESA. The fact that Tanzania's leading trade partners are members of EAC (Kenya) and SADC (especially South Africa) makes it likely that Tanzania may benefit significantly from the two RTAs. The desire to further promote an economic relationship with South Africa was another deciding factor. However, some of the private sector organisations in Tanzania still believe that COMESA was beneficial to Tanzania and tried to reopen the debate as to whether the country could reinstate her membership.

The scope and stage of implementation of trade agreements among the aforementioned RTAs varies. However, trade barriers still remain high in these RTAs and thus it has been observed that intra-regional trade has been minimal and regional member states of these RTAs have not meaningfully benefited economically. This paper therefore 
explores the extent of trade liberalisation in SADC and assesses the economic benefits of Tanzania's membership of SADC.

The rest of the paper is organised as follows. Section 2 discusses the overlapping membership of trade agreements. Section 3 discusses the progress made in liberalising trade within the SADC region. Section 4 discusses the benefits and costs of Tanzania's membership in SADC and Section 5 sets out the conclusions of the paper.

\section{Overlapping Membership of Trade Agreements}

Many countries in eastern and southern Africa belong to more than one RTA as shown in Figure 2. Some of these RTAs have overlapping membership, conflicting objectives and obligations in some cases. This is a case particularly with COMESA/EAC/SADC member states whose integration processes and agenda until recently are inconsistent (Meyer et al. 2010). However, the existing complex and confusing structure of eastern and southern African regionalism is far from an ideal starting point from which to build a regional framework for the 21 st century (Gibb, 2006). The issue of overlapping membership among member states is becoming a burning debate in countries that are members of COMESA/EAC/SADC. Thus, some member states will eventually withdraw from one or more RTAs due to the increasing problems of membership overlaps. Needless to note, deepening of regional integration has also taken place within existing RTAs and includes other areas of integration such as monetary and fiscal integration and other forms of policy cooperation and/or harmonization. This deepening of integration has often been accompanied by a widening of regional agreements (Meyer et al. 2010).

It is a policy choice for a country to join a particular RTA. Tanzania is party to several trade agreements both at the regional and multilateral level. For a poor country such as Tanzania with inadequate resources and human capacity and inefficient institutions, this is considered a daunting challenge, which limits the effectiveness and implementation of agreed protocols (Musonda, 2004). However, it is important to note that RTAs are different in focus, thus Tanzania has different reasons for joining or leaving different regional trade arrangements and hence may decide to speed up the integration process with one while slowing on another. Tanzania is a member of both the EAC and SADC. Under the SADC Protocol on Trade, Tanzania was obliged to dismantle all tariff barriers to all her fellow SADC member states by at least 2012.

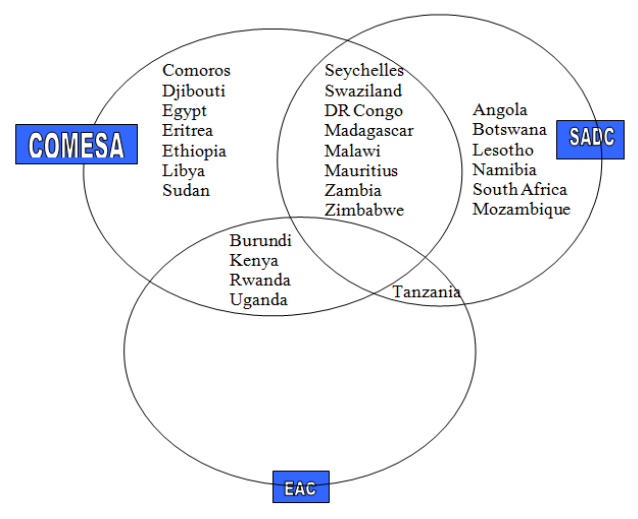

Figure 2 The extent of overlapping membership among EAC, COMESA and SADC 
Conversely, Tanzania is also obliged as a result of its EAC membership to create a EAC common external tariff (CET) that excludes and discriminates against nonEAC-SADC member states. Thus, Tanzania has agreed indirectly and simultaneously to promote free trade with all SADC member countries and to maintain tariff barriers against them at the same time. Other countries in eastern and southern Africa are in exactly similar position and raises similar complexity issues and so are the RTAs with overlapping membership. However, the focus of this paper is on the extent of trade liberalisation in SADC and Tanzania's benefits from being its member discussed in what follows.

\section{Extent of Trade Liberalisation in SADC Region}

SADC, established in 1980 as SADCC, is currently made up of fifteen member states as shown in Table A.1 in Appendix A. The region has a combined population of 223 944179 , a combined GDP at market prices of US\$360 billion and GDP per capita of US $\$ 3152$. For the period 2000-09, intra-SADC exports grew by $9.7 \%$ averaging US $\$ 8112.8$ million while imports grew by $10 \%$ averaging US $\$ 8293.0$ million. The ultimate goal of SADC regional economic cooperation is to transform the organisation into an economic union by 2016 . The path to the creation of the economic union started with the coming into force of a Trade Protocol in 2000 and this led to the creation of a Free Trade Area (FTA) in 2010. This achievement started with the implementation of a series of tariff phase down schedules that was designed to result in $85 \%$ of all trade within SADC being zero duty by 2008 and eventually transform the region into a customs union by 2010 . However, this was not achieved as there were problems which affected the transition. In fact the roadmap towards the achievement of the Customs Union has not been clearly defined.

In assessing the extent of trade liberalisation in SADC and the economic benefits of belonging to the regional trade body, this section uses the two trade indices that are used to evaluate the potential economic effects of a free trade agreement following the suggestions in Plummer et al. (2010). These indicators include: the intraregional trade intensity index to assess the biasness of SADC towards trading among them and the revealed comparative advantage index developed by Balassa (1965) and the results are reported in Tables 1 and 2.

Table 1 shows SADC regional trade intensity indices for the 15 member states and a value that is greater (less) than one indicates trade flow that is larger (smaller) than expected with other SADC member states. The indices seem to suggest that the SADC region is more important as a destination for its members' exports than as a source of their imports. For example, Tanzania's indices although increased to 0.50 for the period 2000-9 are still below one suggesting low dependence of the country on the region for its exports. However, landlocked countries such as Malawi, Zambia and Zimbabwe have a high degree of dependence on regional partners for both exports and imports while non-landlocked countries such as Tanzania have very low dependence on the region.

Table 1 SADC Regional Trade Intensity Indices

\begin{tabular}{|c|c|c|c|c|c|c|c|c|c|c|c|c|c|c|}
\hline \multirow{2}{*}{ country } & \multicolumn{7}{|c|}{ Export intensity } & \multicolumn{7}{|c|}{ Import intensity } \\
\hline & 1980 & 1985 & 1990 & 1995 & 2000 & 2005 & 2009 & 1980 & 1985 & 1990 & 1995 & 2000 & 2005 & 2009 \\
\hline Angola & -1.00 & 0.00 & 0.00 & 0.00 & 0.03 & 0.03 & 0.02 & - & 0.00 & 0.00 & 0.00 & 0.00 & 0.00 & 0.10 \\
\hline Botswana & & & & & & & & - & & & & & & \\
\hline DRC & 0.00 & 0.00 & 0.00 & 0.00 & 0.10 & 0.40 & 1.20 & 0.00 & 0.00 & 0.10 & 0.00 & 0.00 & 0.10 & 0.10 \\
\hline Lesotho & & & & & & & & & & & & & & \\
\hline Madagascar & 0.00 & 0.00 & 0.00 & 0.10 & 0.20 & 0.30 & 0.20 & 0.00 & 0.00 & 0.20 & 0.00 & 0.10 & 0.00 & 0.00 \\
\hline
\end{tabular}




\begin{tabular}{|c|c|c|c|c|c|c|c|c|c|c|c|c|c|c|}
\hline Malawi & 0.00 & 0.10 & 0.20 & 0.20 & 1.50 & 2.20 & 2.10 & 0.10 & 0.10 & 0.00 & 0.10 & 0.10 & 0.30 & 0.10 \\
\hline Mauritius & 0.00 & 0.00 & 0.00 & 0.00 & 0.30 & 0.20 & 0.30 & 0.00 & 0.00 & 0.00 & 0.00 & 0.00 & 0.00 & 0.10 \\
\hline Mozambique & -1.00 & 0.20 & 0.20 & 0.50 & -1.90 & 1.60 & 1.60 & -1.00 & 0.00 & 0.00 & 0.10 & 0.10 & 0.10 & 0.20 \\
\hline Namibia & - & - & - & - & - & 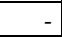 & - & - & - & - & 4 & 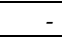 & - & - \\
\hline Seychelles & 0.20 & 0.00 & 0.40 & 0.20 & 0.50 & 0.40 & 0.30 & 0.00 & 0.00 & 0.00 & 0.00 & 0.00 & 0.00 & 0.10 \\
\hline Swaziland & & & & & & & & & & & & & & \\
\hline South Africa & 0.00 & 0.00 & 0.00 & 0.02 & 0.02 & 0.03 & 0.04 & 0.00 & 0.00 & 0.10 & 0.10 & 0.10 & 0.10 & 0.10 \\
\hline Tanzania & $\underline{\underline{0.00}}$ & $\underline{0.00}$ & $\underline{0.00}$ & $\underline{\underline{0.10}}$ & $\underline{0.50}$ & $\underline{0.50}$ & $\underline{0.50}$ & $\underline{\underline{0.00}}$ & $\underline{0.00}$ & $\underline{0.00}$ & $\underline{\underline{0.00}}$ & $\underline{0.10}$ & $\underline{0.10}$ & $\underline{0.00}$ \\
\hline Zambia & 0.00 & 0.10 & 0.20 & 0.10 & 1.50 & 1.20 & 1.40 & 0.00 & 0.10 & 0.00 & 0.10 & 0.10 & 1.00 & 0.30 \\
\hline Zimbabwe & -1.00 & 0.00 & 0.10 & 0.00 & 0.30 & 3.50 & 3.00 & - & 0.10 & 0.10 & \begin{tabular}{l|l|}
0.10 \\
\end{tabular} & 0.20 & 0.30 & 0.20 \\
\hline
\end{tabular}

Table 2, presents the top ten products in which the SADC region has a revealed comparative advantage (RCA). A region or country reveals its comparative advantage in specific products when the RCA indicator scores higher than one, and this shows that its exports of a specific product are more than expected on the basis of comparison to the reference area (Keane et al., 2010). Table 2 seem to suggest that the region has an RCA primarily in agriculture, intermediate goods and ores and minerals and some of these product groups are live trees and other plants, edible fruit and nuts, tobacco, ores, slag and ash, precious metals and base metals.

Table 2 Revealed comparative advantage (RCA) indicators for SADC and rest of the world

\begin{tabular}{|c|l|r|r|r|r|r|r|r|r|r|c|}
\hline HS & \multicolumn{1}{|c|}{ Description } & $\mathbf{2 0 0 0}$ & $\mathbf{2 0 0 1}$ & $\mathbf{2 0 0 2}$ & $\mathbf{2 0 0 3}$ & $\mathbf{2 0 0 4}$ & $\mathbf{2 0 0 5}$ & $\mathbf{2 0 0 6}$ & $\mathbf{2 0 0 7}$ & $\mathbf{2 0 0 8}$ & $\mathbf{2 0 0 9}$ \\
\hline $\begin{array}{l}0 \\
6\end{array}$ & $\begin{array}{l}\text { live tree and other } \\
\text { plants; bulb, root }\end{array}$ & 1.9 & 1.3 & 2.2 & 1 & 1.2 & 1.4 & 7.8 & 2.4 & 3.3 & 6.9 \\
\hline $\begin{array}{l}0 \\
8\end{array}$ & Edible fruit and nuts & 4.5 & 3.5 & 3.9 & 4.2 & 4.7 & 4.4 & 3.7 & 3.9 & 3.9 & 5.3 \\
\hline $\begin{array}{l}2 \\
4\end{array}$ & $\begin{array}{l}\text { Tobacco/manuf. } \\
\text { Tobacco substitutes }\end{array}$ & 8.4 & 7.9 & 5 & 3.2 & 5.9 & 5.4 & 6.4 & 5 & 5.9 & 4.8 \\
\hline $\begin{array}{l}2 \\
6\end{array}$ & Ores, slag and ash & 8.2 & 7.5 & 9.2 & 7 & 6.2 & 6 & 6.4 & 7 & 9.6 & 10.7 \\
\hline $\begin{array}{l}3 \\
6\end{array}$ & $\begin{array}{l}\text { Explosive; pyrotechnic } \\
\text { prod; matches }\end{array}$ & 7.7 & 3.3 & 4.2 & 4.2 & 5.2 & 3.8 & 3.3 & 4 & 5.2 & 4.6 \\
\hline $\begin{array}{l}7 \\
1\end{array}$ & $\begin{array}{l}\text { Precious/semi precious } \\
\text { stones/metals }\end{array}$ & 8.6 & 12.1 & 7.8 & 10.9 & 10.7 & 11.9 & 10.6 & 10 & 8.4 & 5.8 \\
\hline 7 \\
4
\end{tabular}

Source: Derived from data obtained from UNCOMTRADE database; Keane et al. (2010)

Nevertheless, quantitative analyses undertaken such as Keane et al. (2010) suggest that non-tariff barriers (NTBs) reported to UNCTAD-TRAINS disproportionately impact on intra-regional trade in SADC and that these NTBs tend to divert imports away from regional towards non-regional partners. Furthermore, Keane et al. (2010) reveals that most recent trade policy reviews available for SADC members show that most of the NTBs are reported as problematic by traders and these include: competition policy and 
infant industry protection ${ }^{1}$, sanitary and phytosanitary (SPS) standards /technical barriers to trade, rules of origin and customs procedures. Table 3 present reports by exporters/importers and trading partners to SADC secretariat of NTBs imposed by SADC member states for the period 2009 to 2010. The table summarises NTBs registered by or reported against SADC members and shows that SADC member states imposed 305 NTBs against other SADC member states for the period. The table also shows that the greatest number of complaints has been reported by Namibian importers and exporters against Namibia's trading partners (complicated customs procedures and import and export quotas).

Table 3 Types of NTB by SADC members between $21^{\text {st }}$ January, 2009 to $8^{\text {th }}$ June, 2010

\begin{tabular}{|c|c|c|c|c|c|c|c|c|c|c|c|c|c|c|c|c|}
\hline & 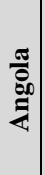 & 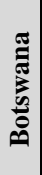 & $\stackrel{u}{0}$ & 咅 & 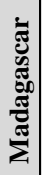 & 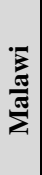 & 窇 & 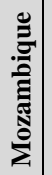 & 涪 & 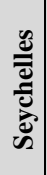 & 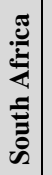 & & ָֻ & 愛 & 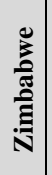 & స్ \\
\hline Grand Total & 9 & 28 & 13 & 14 & 5 & 32 & 3 & 20 & 36 & 16 & 40 & 13 & 19 & 33 & 24 & 305 \\
\hline $\begin{array}{l}\text { 6. Trade related } \\
\text { administrative NTBs }\end{array}$ & 3 & 9 & 2 & 3 & & 6 & 2 & 1 & 6 & 7 & 14 & 4 & 4 & 2 & 5 & 68 \\
\hline $\begin{array}{l}\text { 3.1 Export/Import } \\
\text { licence }\end{array}$ & & 2 & 3 & 2 & 2 & 6 & & & 6 & 5 & 1 & & & 6 & 4 & 37 \\
\hline 5.5 Transit issues & 1 & 7 & 2 & & & 2 & & 5 & 1 & & 2 & & 5 & 7 & 1 & 33 \\
\hline $\begin{array}{l}2 \text { Technical barriers } \\
\text { to trade (TBT) }\end{array}$ & 1 & 4 & 1 & & & 4 & 1 & 2 & 4 & & 6 & & 1 & 2 & 1 & 27 \\
\hline 1. SPS measures & & 1 & & 3 & & 4 & & 1 & 2 & & 5 & & 4 & 4 & 2 & 26 \\
\hline $\begin{array}{l}5.3 \text { Clearance } \\
\text { procedures }\end{array}$ & 1 & & 2 & 1 & & 1 & & 4 & 1 & 4 & 1 & 5 & 1 & 3 & & 24 \\
\hline 7 Payments & 1 & 1 & 1 & 2 & 1 & 1 & & 2 & 1 & & 3 & 1 & 3 & 1 & 2 & 20 \\
\hline 3.2 Quotas & & 3 & & 1 & & 3 & & & 7 & & 2 & & & & 3 & 19 \\
\hline 5.6 Rules of Origin & & & 2 & & 2 & 1 & & 2 & & & 4 & 1 & & 6 & 1 & 19 \\
\hline $\begin{array}{l}5.2 \text { Customs } \\
\text { documentation }\end{array}$ & & 1 & & 1 & & 1 & & & 7 & & 2 & 1 & & & 3 & 16 \\
\hline $\begin{array}{l}5.4 \text { Pre-shipment } \\
\text { inspection }\end{array}$ & 1 & & & & & 3 & & 1 & 1 & & & & 1 & & & 7 \\
\hline $\begin{array}{l}5.1 \text { Customs } \\
\text { valuation }\end{array}$ & & & & & & & & 1 & & & & 1 & & 1 & 2 & 5 \\
\hline $\begin{array}{l}\text { 4. Immigration/ } \\
\text { Consular } \\
\text { requirements cross- } \\
\text { border traders }\end{array}$ & 1 & & & 1 & & & & 1 & & & & & & & & 3 \\
\hline 5.7 Safeguards & & & & & & & & & & & & & & 1 & & 1 \\
\hline
\end{tabular}

However, the main source of NTBs within SADC relate to trade administration imposed by South Africa against other SADC members. Thus the establishment of NTBs seem to stifle intra-regional trade in the SADC region and it has been identified as particularly binding constraint for the economically smaller SADC member states such as Tanzania. On the other hand, exporters and importers trading with Tanzania for the same period reported only 19 NTBs as shown in Table 3 . The table shows that most of these NTBs imposed by Tanzania are trade related administrative measures, transit issues and SPS measures. It's worth noting that Tanzania has a dual membership to EAC and SADC. However, the country's membership in the two overlapping preferential arrangements (EAC Customs Union and SADC FTA) makes the country's

\footnotetext{
${ }^{1}$ These include price controls, quantitative restrictions and other charges intended to protect local industry and /or encourage local processing
} 
trade regime complex as tariff reduction under EAC is not compatible with the SADC requirements and hence Tanzania has had problems implementing the SADC Trade Protocol.

\section{Costs and Benefits of Tanzania's Participation in SADC Trade Arrangement}

\subsection{Benefits that Tanzania derives by participating in SADC}

It is generally argued in international trade theory that countries such as Tanzania and others can benefit from free trade through increased exports and investments. To empirically evaluate the costs and benefits arising out of Tanzania's membership to SADC, the literature on the theory of international trade on the effects of regional economic integration is followed. According to theory, entry into a regional integration scheme can have static effects, which is a result of resource allocation in response to changing relative prices, welfare effects, and dynamic effects, which come from changes in efficiency, ability to exploit economies of scale, and in level of investment and growth (Negasi, 2009). In assessing the benefits and costs, this section rely on trade indices following Plummer et al. (2010) and these are: the trade complimentary index which is a measure of potential trade between two partners (Shirotori \& Molina, 2009), and the revealed comparative advantage indices and the results are reported in Tables 4 and 5. Additionally, the section compares trade flows between Tanzania and her major trading partners before and after joining the SADC free trade area in order to assess any signs of trade creation, trade diversion and welfare effects. The trade complementarities index compares the export basket of one country to the import basket of another country with positive values up to 100 indicating the extent to which the exports of one country matches the imports of another. On the other hand, values of less than zero and negative show that the export and import shares differ greatly suggesting limited potential for intra-regional trade.

Table 4 presents trade complementarities indices constructed for 13 member countries of SADC for which data were available. The table suggests that only South Africa and Mozambique appear to have the composition of exports similar to other SADC members' imports thus suggesting that only these two countries have the potential for high intra-regional trade growth. However, for other members and Tanzania in particular, the table seems to suggest that the compositions of their exports are not conducive to increased intra-regional trade because their export and import baskets differ greatly from each other. For example, a comparison of the relative importance of few export destinations such as Mauritius, Mozambique and South Africa to Tanzania reveal that Tanzania's exports match with the imports of Mauritius and Mozambique only to a small extent as shown in Table 4 with positive indices of 14 and 2 respectively. On the other hand, with a negative index $(-14)$, the results reveal that the country's exports do not match with the imports of South Africa suggesting limited potential for trade between the two countries. This therefore shows that there is limited potential for Tanzania to increase her participation in SADC intra-regional trade.

To further understand what may be the reason behind the similarities in the export and import baskets, RCA indices for Tanzania's top 10 exports have been computed and the results are presented in Table 5. The table reveals that Tanzania has high RCAs in coffee, tea and spices, vegetable textile fibres, yarn, and woven fabrics, ores, slag and ash, pearls, precious stones, metals and coins, and cotton product groups. However, when compared with the rest of the SADC member states and the RCA indices for SADC (see Table 2), Tanzania has similar comparative advantages to the region 
particularly in the top five exports with the exception of meat and edible meat offal $(\mathrm{H} 0-07)$ and oil seed, fruits, grain, seed etc $(\mathrm{H} 0-12)$ products.

\section{Table 4 Trade complementarities indices in SADC}

\begin{tabular}{|c|c|c|c|c|c|c|c|c|c|c|c|c|c|}
\hline & 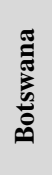 & 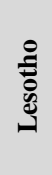 & 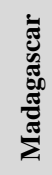 & $\frac{\sqrt{\pi}}{\sum}$ & 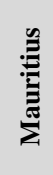 & 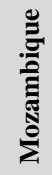 & 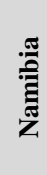 & 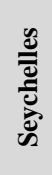 & 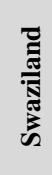 & 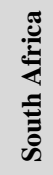 & 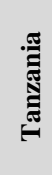 & 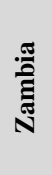 & $\begin{array}{l}\text { है } \\
\text { है } \\
\text { है }\end{array}$ \\
\hline Botswana & & -56 & -35 & -61 & -46 & -53 & -43 & -52 & -50 & -59 & -55 & -53 & -50 \\
\hline Lesotho & -50 & & 19 & -36 & -5 & 15 & -18 & -66 & -34 & 12 & 6 & -36 & 1 \\
\hline Madagascar & -35 & -60 & & -59 & -41 & -18 & -21 & -78 & -43 & -78 & -17 & -3 & -7 \\
\hline Malawi & -61 & -74 & -41 & & -56 & -9 & -21 & -79 & -2 & 22 & -2 & -37 & -16 \\
\hline Mauritius & -46 & -59 & -4 & -48 & & 16 & 9 & -55 & -36 & 32 & 14 & 32 & -4 \\
\hline Mozambiqu & -53 & -74 & -30 & -57 & -54 & & -8 & -76 & -49 & 43 & 2 & -32 & 2 \\
\hline Namibia & -43 & -64 & -28 & -59 & -36 & 6 & & -70 & -31 & 40 & -4 & -25 & -6 \\
\hline Seychelles & -52 & -76 & -19 & -66 & -45 & 16 & 11 & & -48 & 37 & -5 & -24 & -17 \\
\hline Swaziland & -50 & -61 & -9 & -37 & -32 & 22 & -8 & -69 & & 29 & 13 & -30 & -25 \\
\hline South Africa & -59 & -70 & -45 & -72 & -52 & 6 & -16 & -81 & -44 & & -14 & -35 & -31 \\
\hline Tanzania & -55 & -77 & -48 & -71 & -59 & 7 & -13 & -82 & -52 & 46 & & -31 & -24 \\
\hline Zambia & -53 & -79 & -54 & -78 & -62 & 3 & -8 & -83 & -35 & 39 & -23 & & -26 \\
\hline Zimbabwe & -50 & -77 & -25 & -51 & -51 & 11 & -12 & -70 & -39 & 36 & -6 & -23 & \\
\hline
\end{tabular}

Source: Derived from data obtained from UNCOMTRADE database; Keane et al. (2010)

Note: Data for Lesotho are 2004; Swaziland, 2006; Malawi,

Namibia and Seychelles, 2008, all others are 2009

Furthermore, some of the product groups with high RCA such as coffee, tea and spices, vegetable textile fibres, yarn, and woven fabrics, and cotton also differ from the country's top 5 exports.

\section{Table 5 RCA for Tanzania to the rest of the world for the country's top 10 exports}

\begin{tabular}{|c|c|c|c|}
\hline HS & Product Description & Export Value & RCA Indices \\
\hline H0-71 & Pearls, precious stones, metals, coins, etc & 418085782 & 12.00 \\
\hline H0-26 & Ores, slag and ash & 131170956 & 17.50 \\
\hline H0-07 & Meat and edible meat offal & 80199996 & 6.05 \\
\hline H0-08 & Edible fruit, nuts, peel of citrus fruit, melons & 69766251 & 6.40 \\
\hline H0-12 & Oil seed, oleagic fruits, grain, seed, fruit, etc, ne & 43173779 & 5.02 \\
\hline H0-52 & Cotton & 38368590 & 11.61 \\
\hline H0-27 & Edible vegetables and certain roots and tubers & 22856766 & 0.07 \\
\hline H0-44 & Wood and articles of wood, wood charcoal & 13860690 & 1.29 \\
\hline H0-09 & Coffee, tea, mate and spices & 12431043 & 30.18 \\
\hline H0-53 & Vegetable textile fibresnes, paper yarn, woven fabric & 7200757 & 27.93 \\
\hline
\end{tabular}

Source: Derived from data obtained from UNCOMTRADE database; Keane et al. (2010)

It has been argued by authors such as Castro et al. (2004) that implementation of planned FTA has implication on import and export flows and customs revenue. Therefore, Tanzania like many other countries that belong to regional trade organizations has to analyse the effects of implementation of trade protocols on the country's trade policies and the benefits of belonging to such organizations. As discussed earlier countries join RTAs either for political and social reasons or for economic benefits from the bigger markets that RTAs provide. The possible benefits that may accrue to Tanzania for being a member of a RTA include: possible gain in foreign direct investment (FDI), possible gain of export market share in regional markets due to reciprocity and possible gains due to new market location. 
To assess whether the above possible gains have actually accrued to Tanzania, this subsection uses statistical evidence where available. Empirical evidence, however, seems to suggest that in the SADC region, the main driver of trade within the region in terms of exports is South Africa followed by Zambia and Zimbabwe respectively as shown in Table 6. Tanzania's exports to the region have largely remained very low although have increased from $2.60 \%$ in $1980-84$ to $5.10 \%$ in $2005-09$. Keane et al. (2010) argue that South Africa's regional importance is much more pronounced as a source of other SADC members' imports than as a destination for their exports. Despite the low levels of market share for Tanzania's exports to the SADC region, the country's nominal exports have steadily increased over the period 1995-2010 reaching US\$6 billion in 2010 as shown in Figure 3. The figure also shows that inflows of FDI into Tanzania has been increasing since 1998 and reached the peak of about US\$1.2 billion in 2008 although this cannot be directly attributed to SADC membership.

Table 6 SADC intra-regional exports (\% share)

\begin{tabular}{|c|c|c|c|c|c|c|}
\hline Country & 1980-84 & 1985-89 & 1990-94 & 1995-99 & 2000-04 & 2005-09 \\
\hline Angola & 0.90 & 1.10 & 1.10 & 3.60 & 7.00 & 6.60 \\
\hline Botswana & 8.40 & 15.00 & 12.40 & 2.80 & 1.00 & 1.60 \\
\hline DRC & 6.40 & 5.90 & 3.60 & 4.20 & 4.40 & 9.10 \\
\hline Lesotho & 0.20 & 0.30 & 0.20 & 0.00 & 0.00 & 0.00 \\
\hline Madagascar & 0.10 & 0.70 & 1.90 & 3.20 & 3.20 & 2.20 \\
\hline Malawi & 5.90 & 6.80 & 9.50 & 8.60 & 6.80 & 4.40 \\
\hline Mauritius & 0.80 & 1.50 & 2.00 & 6.00 & 6.10 & 3.40 \\
\hline Mozambique & 5.30 & 9.90 & 7.60 & 13.00 & 14.80 & 12.10 \\
\hline Namibia & 0.40 & 0.20 & 1.10 & 0.80 & 0.40 & 0.40 \\
\hline Seychelles & 0.40 & 0.40 & 0.80 & 0.80 & 0.90 & 0.80 \\
\hline Swaziland & 1.50 & 2.70 & 6.00 & 2.10 & 1.10 & 0.80 \\
\hline South Africa & 48.30 & 37.90 & 39.60 & 23.40 & 18.30 & 25.20 \\
\hline Tanzania & $\underline{2.60}$ & $\underline{2.80}$ & $\underline{2.50}$ & $\underline{4.60}$ & $\underline{6.10}$ & $\underline{5.10}$ \\
\hline Zambia & 9.60 & 12.50 & 9.30 & 11.10 & 13.80 & 14.40 \\
\hline Zimbabwe & 10.80 & 5.00 & 8.30 & 18.00 & 17.20 & 14.70 \\
\hline
\end{tabular}

Source: IMF Direction of Trade Statistics; Keane et al. (2010)

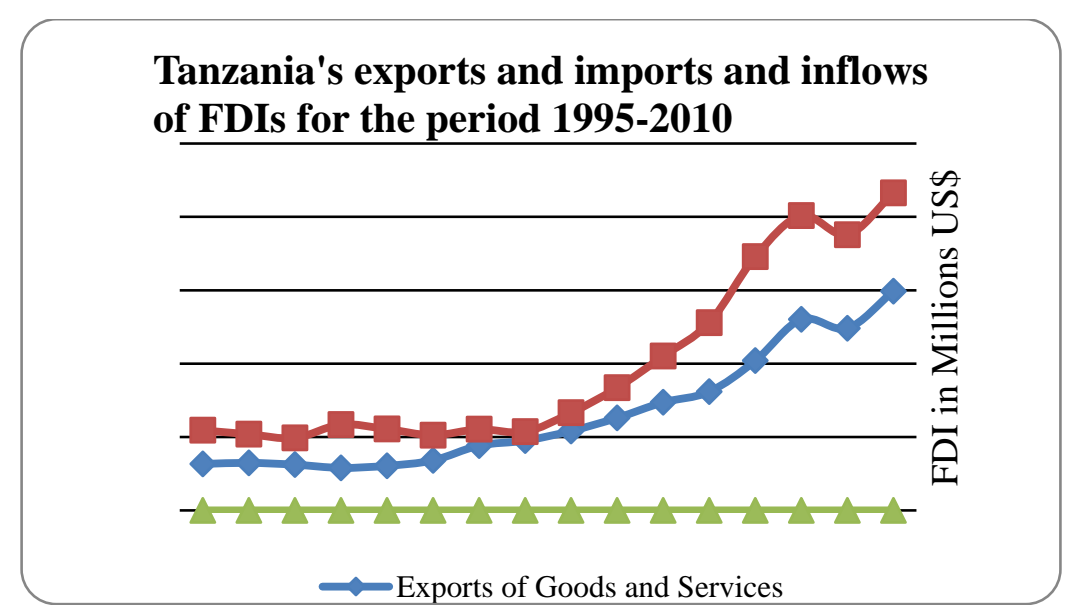

Figure 3 Tanzania's exports and imports and inflows of FDIs for the period 1995-2010

Source: Authors' compilation based on data derived from UN COMTRADE database and UNCTADstat data base for FDI data 


\subsection{Costs associated with Tanzania's membership to SADC}

The fiscal effect of trade liberalization of economies essentially involves a loss of government import tariff revenue, particularly where governments have not put in place appropriate measures to expand alternative sources of revenues (Matambalya, 2001). This is a critical problem that has been left unaddressed in small open economies such as Tanzania. The problem with such rapid revenue losses and general costs is that they undermine the member states' ability to fund the day-to-day operations of its own country, especially given the fact that Tanzania is very much reliant on donor funding to support its national budget. In other words, small open economies require increased direct donor funding of national budgets, or significant speedy support for tax diversification to replace lost revenue and to avoid undermining state functioning and national development programmes.

In summary Tanzania has suffered losses as a result of her membership to the economic groupings and has faced NTBs in accessing the SADC market and these include: possible loss of protection for infant domestic industry and loss of tariff revenue as tariffs on imports go down or are eliminated among others. Specifically the removal of tariffs in intra-SADC trade may result in Tanzania losing tariff revenue as has happened when EAC became a customs union. It has been argued that Tariff duties and VAT on imports are the most important sources of customs revenue in Tanzania. Castro et al. (2004) estimated that in 2001-02 customs revenue accounted for 8.5\% of Tanzania's total revenue. Off the total customs revenue collected in 2002, Tariff duties and VAT on imports accounted for $45.3 \%$ and $42.3 \%$ respectively thus suggesting that customs revenue is mainly consisted of revenue from Tariff duties and VAT on imports in Tanzania. To illustrate further the impact of tariff reduction or tariff removal on Tanzania's revenue as a result of joining an RTA, when Tanzania joined the EAC Customs Union in 2004, the country lost an estimated revenue amounting to US\$19 million (4.2\% of customs revenue) (US $\$ 40$ million with the suspended duties) without the duties which were suspended but phased out over a period as shown in Figure A.2 in Appendix A.

On the other hand, withdrawing from an RTA can result in a country's exporters losing the market for their exports as happened when Tanzania withdrew from COMESA in 2000. Ng'andu (2008) estimates that the country lost on average per year for the period 2000-2005, exports amounting to US\$73.3 million totalling US\$366.5 million in value terms for the five year period as shown in Table A.3 in Appendix A. Table A.4 in Appendix A shows a sample of Tanzanian companies that had lost the COMESA market after the country withdrew from the RTA in 2000. This can equally happen if Tanzania was to withdrawal its membership from SADC.

\section{Conclusion}

The paper has explored the extent of trade liberalisation in SADC and has also assessed the economic benefits of Tanzania's membership to the RTA. The paper's findings seem to suggest that SADC is far behind the schedule of transforming the region in a Customs Union. The region still maintains a lot of NTBs and is at the FTA level. The study has revealed that SADC intra-regional trade is very low and that only South Africa and Mozambique seem to have the potential to increase intra-regional trade and benefits from SADC.

The study has found that Tanzania's economic benefits from SADC membership have been minimal. However, its nominal exports and exports market share have steadily been increasing since the mid-1990s and so have the inflows of FDIs. At the moment Tanzania does not suffer adversely from its dual membership of EAC and SADC regional integration initiatives. However, Tanzania's membership in overlapping RTAs 
has made its trade regime complex while tariff reductions under EAC is not compatible with SADC requirements hence the country has had problems implementing the SADC Trade Protocol. The country therefore may not need to withdraw its membership from either EAC or SADC. In the long-term the country will do well to advocate for a harmonisation of the EAC and SADC trade regimes, possibly through the mechanism of the proposed COMESA-EAC-SADC Tripartite FTA.

\section{References}

African Union (2010), Trade Liberalisation, Investment and Economic Integration in African Regional Economic Communities towards the African Common Market and Economic Community, Report presented at the AU Conference of Ministers of Trade, $6^{\text {th }}$ Ordinary Session, $29^{\text {th }}$ October-November 2010, Kigali, Rwanda.

Alves, P., Draper, P., Halleson, D. (2007), SACU, Regional Integration and the Overlap Issue in Southern Africa: From Spaghetti to Cannelloni? Trade Policy Report, 15, Johannesburg: South African Institute of International Affairs.

Balassa, B. (1965), Trade Liberalisation and Revealed Comparative Advantage, The Manchester School, 33, pp. 99-123.

Castro, L., Kraus, C., Rocha de la, M. (2004), Regional Integration in East Africa: Trade and Revenue Impacts of the Planned East African Community Customs Union, Africa Region Working Paper Series, 72, Washington, DC: World Bank.

EAC (1999), Protocol on the Establishment of the East African Customs Union, Arusha, EAC.

EAC (2007), Common External Tariff for the EAC, Arusha, EAC.

EAC (2011), East African Community Facts and Figures-2011, Arusha, EAC.

Flatters, F. (2002), SADC Rules of Origin: Undermining Regional Free Trade. Trade and Industrial Policy Strategies, Forum Paper. Johannesburg South Africa, September 9-11, 2002.

Gibb, R. (2006), Rationalisation or Redundancy?Making Eastern and Southern Africa's Regional Trade Units Relevant, Brenthurst Discussion Paper, 3.

Hartzenberg, T. (2011), Regional Integration in Africa, World Trade Organisation, Staff Working Papers ERSD.

Hurt, S. R. (2010), The EU-SADC Economic Partnership Agreement Negotiations. 'Locking-in' the Neoliberal Development Model in Southern Africa?, Paper prepared for Jean Monnet Centre of Excellency Workshop: Diverging Paradigms in EU Trade Policy, KatholiekeUniversiteit Leuven, 16-17 December 2010.

Kalaba, M. (2009), Exploring the COMESA-EAC-SADC Trilateral Free Trade Area: an approach to Rules of Origin; Trade and Industrial Policy strategies. Paper presented at the Sixth Southern African Forum on Trade.

Keane, J., Massimiliano, C. And Kennan, J. (2010).Impediments to Intra-Regional Trade in Sub-Saharan Africa. Paper prepared for the Commonwealth Secretariat. London: Overseas Development Institute.

Kweka, J., Mboya, F. (2004), Regional Integration and Poverty: The case of Tanzania. Meyer, N. et al. (2010), Bilateral and Regional Trade Agreements and Technical Barriers to Trade: An African Perspective, OECD Trade Policy Working Papers, 96.

Negasi, M. Y. (2009), Trade Effects of Regional Economic Integration in Africa. The Case of SADC. Paper drafted for the Services Sector Development and Impact on Poverty Thematic Working Group Working Paper, available at http://www.tips.org.za/files/13.Trade_effects_of_Regional_Economic_Integrat ion-SSD.pdf

Ng'andu, B. K. E. (2008), Zambia's Dual Membership of COMESA and SADC. A Study Commissioned by Zambia Business Forum with support from Market Access Trade and Enabling Policies and Zambia Threshold Project. 
Plummer, M. G., Cheong, D., Hamanaka, S. (2010), Methodology for Impact Assessment of Free Trade Agreement, Mandaluyong City, Asian Development Bank.

Shirotori, M., Molina, A. (2009), South-South Trade: The Reality Check, Issues in New Economic Geography of Trade, United Nations Conference on Trade and Development: Geneva, available at http://www.unctad.org/ditc/tab/publications/DITC-TAB-2008-1-final17MARCH2009.pdf

UNECA (2011), Establishment of Inter-REC's Free Trade Areas in Africa Drawing on Lessons from the COMESA-SADC-EAC FTA Experience, Addis Ababa, UNECA.

Wanga, G., Matambalya, F.T. (2001), Southern African Development Community and Poverty Alleviation: An Overview, Presented at the Southern African Regional Integration Conference, St. George's Hotel, Johannesburg, 19th and 20th July 2001. 


\section{Appendices}

Appendix A

Table A.1 Summary of International Trade Agreements for Tanzania

\begin{tabular}{|c|c|c|c|c|c|c|}
\hline Agreement & $\begin{array}{l}\text { Member } \\
\text { countries }\end{array}$ & $\begin{array}{c}\text { Membership } \\
\text { for } \\
\text { Tanzania } \\
\text { (year) }\end{array}$ & $\begin{array}{c}\text { Nature of } \\
\text { the } \\
\text { Agreement }\end{array}$ & $\begin{array}{l}\text { Current } \\
\text { Status }\end{array}$ & $\begin{array}{l}\text { GDP } \\
\text { per } \\
\text { capita } \\
\text { (US\$) } \\
\end{array}$ & $\begin{array}{c}\text { Total } \\
\text { Population }\end{array}$ \\
\hline COMESA & $\begin{array}{l}\text { Burundi, } \\
\text { Comoros, DR } \\
\text { Congo, } \\
\text { Djibouti, } \\
\text { Egypt, } \\
\text { Eritrea, } \\
\text { Ethiopia, } \\
\text { Kenya, Libya, } \\
\text { Madagascar, } \\
\text { Malawi, } \\
\text { Mauritius, } \\
\text { Rwanda, } \\
\text { Seychelles, } \\
\text { Sudan, } \\
\text { Swaziland, } \\
\text { Uganda, } \\
\text { Zambia, } \\
\text { Zimbabwe }\end{array}$ & $\begin{array}{c}1995 \text { - } \\
\text { endorsed } \\
2000- \\
\text { withdrew }\end{array}$ & $\begin{array}{l}\text { started with } \\
\text { Free Trade } \\
\text { Area } \\
\text { (FTA) and } \\
\text { now in } \\
\text { progress to } \\
\text { establish } \\
\text { Custom } \\
\text { Union }\end{array}$ & $\begin{array}{l}\text { Customs } \\
\text { Union }(\mathrm{CU}) \\
\text { launched } \\
2010\end{array}$ & 1,811 & $406,102,471$ \\
\hline SADC & $\begin{array}{l}\text { Angola, } \\
\text { Botswana, } \\
\text { DR Congo, } \\
\text { Lesotho, } \\
\text { Malawi, } \\
\text { Mauritius, } \\
\text { Madagascar, } \\
\text { Mozambique, } \\
\text { Namibia, } \\
\text { Seychelles, } \\
\text { South Africa, } \\
\text { Swaziland, } \\
\text { Tanzania, } \\
\text { Zambia, } \\
\text { Zimbabwe }\end{array}$ & $\begin{array}{l}1992 \text { - signed } \\
\text { the } \\
\text { declaration } \\
\text { and treaty } \\
1996 \text { - adopt } \\
\text { SADC } \\
\text { protocol in } \\
\text { Trade }\end{array}$ & $\begin{array}{l}\text { Establish a } \\
\text { FTA in } \\
\text { SADC } \\
\text { region by } \\
2008 \text { and } \\
\text { CU by } \\
2010 \text { and } \\
\text { Common } \\
\text { Market by } \\
2015\end{array}$ & $\begin{array}{c}\text { FTA } \\
\text { launched } \\
\text { 2010. CU } \\
\text { postponed } \\
\text { (indefinitely) }\end{array}$ & 3,152 & $233,944,179$ \\
\hline EAC & $\begin{array}{l}\text { Burundi, } \\
\text { Kenya, } \\
\text { Rwanda, } \\
\text { Tanzania, } \\
\text { Uganda }\end{array}$ & $\begin{array}{l}1999 \text { - signed } \\
\text { the treaty } \\
2000 \text { - } \\
\text { ratified by } \\
\text { Parliament }\end{array}$ & $\begin{array}{l}\text { Regional } \\
\text { trade } \\
\text { Integration } \\
\text { with } \\
\text { Custom } \\
\text { Union as } \\
\text { the entry } \\
\text { point }\end{array}$ & $\begin{array}{c}\text { Custom } \\
\text { Union signed } \\
\text { in March, } \\
\text { 2004, EALA } \\
\text { unanimously } \\
\text { approved the } \\
\text { Custom } \\
\text { Management } \\
\text { Bill in } \\
\text { December } \\
2004\end{array}$ & 685 & $133,100,000$ \\
\hline
\end{tabular}

Source: EAC, 2011 
Table A.2 Tanzania: Customs revenue change by sector in EAC Customs Union

\begin{tabular}{|c|c|c|c|c|c|}
\hline \multirow[b]{2}{*}{ Sector } & \multirow{2}{*}{$\begin{array}{c}\text { Share } \\
\text { of total } \\
\text { imports } \\
(\%)\end{array}$} & \multirow{2}{*}{$\begin{array}{c}\text { Change in } \\
\text { tariff } \\
\text { protection* }\end{array}$} & \multicolumn{2}{|c|}{$\begin{array}{c}\text { Change in } \\
\text { customs revenue }\end{array}$} & \multirow{2}{*}{$\begin{array}{c}\text { Revenue loss } \\
\text { from elimination } \\
\text { of suspended } \\
\text { duties }(\%)\end{array}$} \\
\hline & & & $\begin{array}{l}\text { In US\$ } \\
\text { million }\end{array}$ & $\begin{array}{c}\% \text { of } \\
\text { customs } \\
\text { revenue }\end{array}$ & \\
\hline $\begin{array}{l}\text { Food and live } \\
\text { animals }\end{array}$ & 12.2 & 1 & -9.0 & -2.02 & 23 \\
\hline $\begin{array}{l}\text { Beverages and } \\
\text { tobacco }\end{array}$ & 0.8 & -29 & -0.4 & -0.09 & 0.2 \\
\hline $\begin{array}{l}\text { Crude } \\
\text { materials, } \\
\text { inedible, } \\
\text { except fuels }\end{array}$ & 3.1 & 6 & -7.9 & -1.79 & 0.0 \\
\hline $\begin{array}{l}\text { Mineral fuels, } \\
\text { lubricants and } \\
\text { related } \\
\text { materials }\end{array}$ & 0.5 & n.a. & 0.1 & 0.02 & 0.0 \\
\hline $\begin{array}{l}\text { Animal and } \\
\text { vegetable oils, } \\
\text { fats and waxes }\end{array}$ & 4.2 & -25 & -0.8 & -0.18 & 35.2 \\
\hline $\begin{array}{l}\text { Chemicals } \\
\text { and related } \\
\text { products }\end{array}$ & 14.1 & -36 & -3.7 & -0.83 & 1.3 \\
\hline $\begin{array}{l}\text { Manufactured } \\
\text { goods } \\
\text { classified } \\
\text { chiefly by } \\
\text { material } \\
\end{array}$ & 18.5 & -16 & 18.2 & 4.12 & 30.4 \\
\hline $\begin{array}{l}\text { Machinery } \\
\text { and transport } \\
\text { equipment }\end{array}$ & 40.0 & -39 & -17.1 & -3.85 & 5.0 \\
\hline $\begin{array}{l}\text { Miscellaneous } \\
\text { manufactured } \\
\text { articles }\end{array}$ & 6.7 & -10 & 1.7 & 0.39 & 4.7 \\
\hline $\begin{array}{l}\text { Commodities } \\
\text { and } \\
\text { transactions } \\
\text { not classified } \\
\text { elsewhere }\end{array}$ & 0.0 & -6 & 0.0 & 0 & 0.0 \\
\hline Total & 100 & -48 & -18.78 & -4.24 & 100 \\
\hline
\end{tabular}


Table A.3 Determination of loss and potential of COMESA market

\begin{tabular}{|c|c|c|c|c|c|}
\hline & Company & $\begin{array}{c}\text { Average } \\
\text { Export } \\
\text { value } \\
\text { (million) } \\
\text { per year } \\
1997 \text { - } \\
2000\end{array}$ & $\begin{array}{c}\text { Average } \\
\text { Export } \\
\text { value } \\
\text { (million) } \\
\text { per year } \\
2000- \\
2005\end{array}$ & $\begin{array}{c}\text { Estimated } \\
\text { Export } \\
\text { potential in } \\
\text { future } \\
\text { (million) }\end{array}$ & Comments or Observations \\
\hline 1 & $\begin{array}{l}\text { Soap and Allied } \\
\text { Industries Ltd }\end{array}$ & $<\mathrm{US} \$ 0.5$ & $<\mathrm{US} \$ 1.5$ & $<\mathrm{US} \$ 1.8$ & $\begin{array}{l}\text { Increased production will } \\
\text { allow the company to export } \\
\text { much more }\end{array}$ \\
\hline 2 & $\begin{array}{l}\text { Aluminium Africa } \\
\text { Ltd }\end{array}$ & US\$ 1.2 & US \$ 1.10 & $<\mathrm{US} \$ 1.5$ & $\begin{array}{l}\text { Company estimated potential } \\
\text { US } \$ 26 \text { million }\end{array}$ \\
\hline \multirow[t]{3}{*}{3} & $\begin{array}{l}\text { Sumaria Group } \\
\text { (i) Simba Plastic } \\
\text { Ltd }\end{array}$ & NIL & US \$ 0.55 & US\$ 1.2 & \multirow{3}{*}{$\begin{array}{l}\text { Exports value of Shelly's } \\
\text { Pharmaceutical Co. Ltd not } \\
\text { included as medicines enjoy } \\
\text { duty free status in most } \\
\text { COMESA states }\end{array}$} \\
\hline & (ii) SDL Ltd & US $\$ 0.15$ & US \$ 0.35 & US\$ 1.0 & \\
\hline & $\begin{array}{l}\text { (iii) Nyanza } \\
\text { Bottling }\end{array}$ & NIL & NIL & US\$ 0.42 & \\
\hline 4 & $\begin{array}{l}\text { Panasonic Battery } \\
\text { Co.Ltd }\end{array}$ & US\$ 0.90 & US $\$ 0.22$ & US\$ 2.0 & $\begin{array}{l}\text { Company's product quality } \\
\text { much better than most } \\
\text { imported Dry cell Batteries }\end{array}$ \\
\hline 5 & $\begin{array}{l}\text { KiboMatch Group } \\
\text { Ltd }\end{array}$ & US \$ 3.6 & US\$ 2.1 & US\$ 3.0 & $\begin{array}{l}\text { Company looks forward for } \\
\text { export expansion. }\end{array}$ \\
\hline 6 & Metal products & NIL & US \$ 1.3 & US\$ 3.2 & $\begin{array}{l}\text { Looks forward for export } \\
\text { expansion }\end{array}$ \\
\hline 7 & Mbeya Cement & NA & US $\$ 4.0$ & US\$ 6.0 & $\begin{array}{l}\text { Company exports and } \\
\text { believes it can increase }\end{array}$ \\
\hline 8 & $\begin{array}{l}\text { PANAFORA (Pan } \\
\text { African enterprises } \\
\text { subsidiary) }\end{array}$ & $\begin{array}{l}\text { Company } \\
\text { not } \\
\text { established }\end{array}$ & US \$ 0.2 & US\$ 0.6 & $\begin{array}{l}\text { Has started in } 2005 \text { to export } \\
\text { to Malawi \& Mozambique } \\
\text { and is moving to Congo } \\
\text { (DR), Zambia, Rwanda \& } \\
\text { Burundi }\end{array}$ \\
\hline 9 & ABB Tannlec Ltd & NA & NA & NA & $\begin{array}{l}\text { Export to many COMESA } \\
\text { Countries }\end{array}$ \\
\hline 10 & OK Plast Ltd & $\begin{array}{l}1997- \\
0.75 \\
1998- \\
0.762 \\
1999- \\
0.816 \\
2000- \\
0.647\end{array}$ & $\begin{array}{l}2001- \\
0.36375 \\
2002- \\
0.34125 \\
2003- \\
0.2891 \\
2004- \\
0.25215 \\
2005- \\
0.267,25 \\
\end{array}$ & $\begin{array}{l}\text { US\$ } \\
0.85\end{array}$ & $\begin{array}{l}\text { Company produces Sandals } \\
\& \text { slippers and Competes } \\
\text { with a lot of imports in } \\
\text { COMESA Countries. }\end{array}$ \\
\hline 11 & $\begin{array}{l}\text { Tea Industries (Tea } \\
\text { Board ofTanzania) }\end{array}$ & US\$9.4 & US $\$ 10.0$ & US\$ 16.0 & $\begin{array}{l}\text { Tea is sold via Auction in } \\
\text { Mombasa and can export to } \\
\text { COMESA Market }\end{array}$ \\
\hline 12 & $\begin{array}{l}\text { Tanzania Tobacco } \\
\text { Board }\end{array}$ & NIL & NA & US\$ 2-3 & $\begin{array}{l}\text { States that they can export } \\
\text { this figure to Egypt alone per } \\
\text { year and this would boost } \\
\text { farmer's morale } \\
\text { \&production in } \\
\text { Ruvuma. }\end{array}$ \\
\hline 13 & Unilever (Tz) Ltd & $\begin{array}{l}\text { Not } \\
\text { Applicable }\end{array}$ & $\begin{array}{l}0.7 \\
\text { exported } \\
\text { by end of } \\
2006\end{array}$ & US\$ 1.5 & $\begin{array}{l}\text { Company can export to } \\
\text { Zambia and Malawi but } 30 \% \\
\text { duty is the problem. Uniliver } \\
\text { Kenya exports via Tunduma } \\
\text { in spite of heavy transport } \\
\text { costs. }\end{array}$ \\
\hline
\end{tabular}




\begin{tabular}{|c|c|c|c|c|c|}
\hline 14 & $\begin{array}{l}\text { Mukwano } \\
\text { Industries soap }\end{array}$ & $\begin{array}{l}\text { Not } \\
\text { Applicable }\end{array}$ & 0.4 & US \$ 1.2 & $\begin{array}{l}\text { Exports to Malawi and pays } \\
\text { duty now. In February } 2006 \\
\text { it exported soap noodles of } \\
\text { US } \$ 33,000\end{array}$ \\
\hline 15 & $\begin{array}{l}2000 \text { Industries } \\
\text { soap noodles }\end{array}$ & $\begin{array}{l}\text { Not } \\
\text { Applicable }\end{array}$ & 0.1 & US\$ 0.5 & $\begin{array}{l}\text { Exports to Malawi and may } \\
\text { be to other countries too. }\end{array}$ \\
\hline 16 & MURZAH OIL & $\begin{array}{l}\text { Not } \\
\text { Applicable }\end{array}$ & 0.5 & US\$ 1.5 & $\begin{array}{l}\text { Exports to Zambia \& } \\
\text { Malawi now. }\end{array}$ \\
\hline 17 & Kioo Ltd & $\begin{array}{l}1998- \\
\text { US\$ } 3.4 \\
1999- \\
\text { US\$ } 2.0 \\
2002- \\
\text { US\$ } 2.0\end{array}$ & $\begin{array}{l}2001-3.1 \\
2002-5.2 \\
2003-5.0 \\
2004-0.5 \\
\text { average } \\
\text { US\$ } 5.3\end{array}$ & US\$ $12-15$ & $\begin{array}{l}\text { Export figures exclude } \\
\text { exports to Kenya and } \\
\text { Uganda } \\
\text { Kioo Ltd exported a lot also } \\
\text { to Madagascar, Angola, } \\
\text { Djibouti the so-called distant } \\
\text { markets. } \\
\text { Kioo Ltd lost export orders } \\
\text { to Zimbabwe and Malawi in } \\
2003 \text { due to lack of } \\
\text { preferential tariffs (US\$ } 2 \\
\text { million) }\end{array}$ \\
\hline 18 & $\begin{array}{l}\text { Tanzania } \\
\text { Breweries Ltd }\end{array}$ & NA & $\begin{array}{l}2001- \\
\text { US } \$ 0.104 \\
2002- \\
\text { US } \$ 0.312 \\
2003- \\
\text { US } \$ 0.286 \\
2003- \\
\text { US } \$ 0.167 \\
\text { Average } \\
\text { US } \$ 0.250 \\
\end{array}$ & & $\begin{array}{l}\text { TBL lost an export order of } \\
\text { millions of dollars to } \\
\text { Mauritius in } 2002-2003 \\
\text { due to lack of COMESA } \\
\text { preferential tariffs. The } \\
\text { company has capacity to } \\
\text { export when playing field } \\
\text { levelled. }\end{array}$ \\
\hline 19 & $\begin{array}{l}\text { Tanzania China } \\
\text { Friendship textiles } \\
\text { Co. Ltd }\end{array}$ & $\begin{array}{l}\text { US \$ } \\
0.18566\end{array}$ & $\begin{array}{l}\text { US \$ } \\
0.87152\end{array}$ & US\$ 3.0 & $\begin{array}{l}\text { The company exports mainly } \\
\text { via small scale cross border } \\
\text { traders, but when they can } \\
\text { export without paying duty } \\
\text { the opportunity will be open, } \\
\text { as tax on textile imports are } \\
\text { very } \\
\text { high. }\end{array}$ \\
\hline 20 & Raffia Bags Ltd & NA & $\begin{array}{l}2002 \text { - US } \\
\$ 0.2 \\
\text { Average } \\
\text { US \$ } 1.5\end{array}$ & NA & $\begin{array}{l}\text { By 2003/4 Raffia bags } \\
\text { negotiated and is exporting } \\
\text { cement bags duty free to } \\
\text { Zambia. When duty free is } \\
\text { extended on } \\
\text { all its products the exports } \\
\text { can be boosted. }\end{array}$ \\
\hline 21 & A to Z Ltd & NA & NA & NA & $\begin{array}{l}\text { The company is exporting } \\
\text { mosquito net duty free to } \\
\text { COMESA Countries and T- } \\
\text { Shirts to Malawi \& South } \\
\text { Africa. T-Shirts will enjoy } \\
\text { duty free status in COMESA }\end{array}$ \\
\hline \multirow[t]{2}{*}{22} & Sunflag (T) Ltd & NA & NA & $<\mathrm{US} \$ 1.2$ & $\begin{array}{l}\text { The company is exporting } \\
\text { mosquito net duty free to } \\
\text { COMESA Countries and T- } \\
\text { Shirts to Malawi \& South } \\
\text { Africa. T-Shirts will enjoy } \\
\text { duty free status in COMESA }\end{array}$ \\
\hline & $\begin{array}{l}\text { Total Estimate } \\
18.45\end{array}$ & 28.70 & US $\$ 73.3$ & & \\
\hline
\end{tabular}

Source: Ng'andu, 2008 


\section{Table A.4 A sample of companies which had lost COMESA export market after Tanzania's withdrawal}

\begin{tabular}{|c|c|c|c|c|}
\hline & Company & $\begin{array}{c}\text { Date of } \\
\text { statement } \\
\text { made on loss } \\
\text { of market }\end{array}$ & $\begin{array}{l}\text { Potential } \\
\text { importing } \\
\text { country }\end{array}$ & Observing \\
\hline 1 & $\begin{array}{l}\text { Karibu Textiles } \\
\text { Mills Ltd }\end{array}$ & $2000-2001$ & Malawi, Zambia & $\begin{array}{l}\text { U s e d to ex port to Ma la } \\
\text { w i \& Zambia but has stooped. }\end{array}$ \\
\hline 2 & Mac Group Ltd & 20th May, 2003 & Rwanda, Burundi & $\begin{array}{l}\text { States it can export even more to } \\
\text { other COMESA Countries. }\end{array}$ \\
\hline 3 & $\begin{array}{l}\text { Tanzania } \\
\text { Breweries Ltd }\end{array}$ & $\begin{array}{l}\text { 23rd May, } 2003 \\
\& 2005\end{array}$ & $\begin{array}{l}\text { Mauritius, } \\
\text { Malawi, Congo } \\
\text { (DR) and Zambia }\end{array}$ & $\begin{array}{l}\text { Still exporting a little to Malawi, } \\
\text { DRC, Zambia and Kenya. }\end{array}$ \\
\hline 4 & $\begin{array}{l}\text { Tanga Cement Co. } \\
\text { Ltd }\end{array}$ & $\begin{array}{l}\text { On 13th May, } \\
2003 \text { Letter to } \\
\text { CTI }\end{array}$ & Rwanda, Burundi & $\begin{array}{l}\text { Stopped exports in } 2001 \text { but states } \\
\text { it longer needs export markets and } \\
\text { wants protection. }\end{array}$ \\
\hline 5 & $\begin{array}{l}\text { Sabuni Industries } \\
\text { Ltd }\end{array}$ & $2000-2001$ & Rwanda, Burundi & $\begin{array}{l}\text { Reduced exports but can export } \\
\text { more to Malawi, Zambia and } \\
\text { DRC. }\end{array}$ \\
\hline 6 & $\begin{array}{l}\text { Tanzania Cigarette } \\
\text { Co. Ltd }\end{array}$ & 2005 & $\begin{array}{l}\text { Malawi, Zambia, } \\
\text { Congo (DR), } \\
\text { Rwanda and } \\
\text { Burundi }\end{array}$ & $\begin{array}{l}\text { Exports a little to Malawi, } \\
\text { Mozambique. Zambia BAT } \\
\text { Cigarette factory is closed and } \\
\text { will depend on imported } \\
\text { cigarettes. }\end{array}$ \\
\hline 7 & $\begin{array}{l}\text { Aluminium Africa } \\
\text { Ltd }\end{array}$ & $2003 \& 2005$ & $\begin{array}{l}\text { Malawi, Zambia, } \\
\text { Rwanda and } \\
\text { Burundi }\end{array}$ & $\begin{array}{l}\text { Still exports smaller amounts due } \\
\text { to tariffs. But company capacity } \\
\text { requires a lager COMESA } \\
\text { Market. }\end{array}$ \\
\hline 8 & $\begin{array}{l}\text { Tanzania Portland } \\
\text { Cement Co. Ltd } \\
\text { (Twiga) }\end{array}$ & 26th June, 2003 & $\begin{array}{l}\text { Used to export to } \\
\text { Rwanda, } \\
\text { Burundi, Malawi, } \\
\text { Mozambique }\end{array}$ & $\begin{array}{l}\text { Stopped exports but can export } \\
\text { also to DRC, Comoros and } \\
\text { Seychelles. It is now } \\
\text { concentrating on the local market. }\end{array}$ \\
\hline 9 & Raffia Bags Ltd & $\begin{array}{l}\text { 10th May, } 2003 \\
\& 2005\end{array}$ & Malawi, Zambia & $\begin{array}{l}\text { Still exporting some and can } \\
\text { export also to DRC, Rwanda, } \\
\text { Burundi, Comoros \& Zimbabwe. } \\
\text { Raffia Bags, Cement bags are } \\
\text { exported to Zambia Chilanga } \\
\text { Cement free of duty following } \\
\text { Raffia bags negotiations. }\end{array}$ \\
\hline 10 & $\begin{array}{l}\text { Sita Steel Rolling } \\
\text { Mills Ltd }\end{array}$ & 9th July 2003 & $\begin{array}{l}\text { Malawi, Congo } \\
\text { (DR), and } \\
\text { Rwanda }\end{array}$ & $\begin{array}{l}\text { Can export also to Zambia and } \\
\text { Burundi. It is an engineering } \\
\text { company which requires a bigger } \\
\text { market. }\end{array}$ \\
\hline 11 & Kioo Ltd & $\begin{array}{l}\text { 2nd February } \\
2004\end{array}$ & $\begin{array}{l}\text { Zambia, } \\
\text { Zimbabwe, } \\
\text { Malawi, } \\
\text { Madagascar, } \\
\text { Angola, Congo } \\
\text { (DR), Burundi, } \\
\text { Ethiopia, Djibouti, } \\
\text { Mauritius, } \\
\text { Seychelles. } \\
\end{array}$ & $\begin{array}{l}\text { Still exporting some but has } \\
\text { capacity to double exports. Has } \\
\text { modern state of the art machinery } \\
\text { which depends on a large } \\
\text { COMESA Market for its } \\
\text { viability. }\end{array}$ \\
\hline 12 & $\begin{array}{l}\text { Tanzania China } \\
\text { Friendship Textiles }\end{array}$ & 2005 & $\begin{array}{l}\text { Malawi, Zambia, } \\
\text { Congo (DR), } \\
\text { Comoros. }\end{array}$ & $\begin{array}{l}\text { Currently exports are through } \\
\text { Small Scale Cross border Traders } \\
\text { but with free duty in COMESA, it } \\
\text { can export various fabrics. }\end{array}$ \\
\hline 13 & Sunflag (T) Ltd & 2005 & $\begin{array}{l}\text { Export to South } \\
\text { Africa, Kenya \& } \\
\text { Uganda }\end{array}$ & $\begin{array}{l}\text { Export expansion \& production } \\
\text { need the COMESA Market. }\end{array}$ \\
\hline 14 & $\begin{array}{l}\text { ABB Tanelec }(\mathrm{T}) \\
\text { Ltd }\end{array}$ & 2005 & $\begin{array}{l}\text { Exports to Malawi, } \\
\text { Zambia, Congo } \\
\text { (DR), Rwanda, }\end{array}$ & $\begin{array}{l}\text { Still exports some and has } \\
\text { potential } \\
\text { to compete with South Africa in }\end{array}$ \\
\hline
\end{tabular}




\begin{tabular}{|c|c|c|c|c|}
\hline & & & $\begin{array}{l}\text { Burundi, Angola, } \\
\text { Kenya, Uganda } \\
\text { \& Zimbabwe }\end{array}$ & $\begin{array}{l}\text { COMESA Countries as its market } \\
\text { share is the East \& central Africa } \\
\text { Region. }\end{array}$ \\
\hline 15 & $\begin{array}{l}\text { general Tyre East } \\
\text { African Ltd }\end{array}$ & 2005 & $\begin{array}{l}\text { Now exports } \\
\text { toKenya } \\
\text { andUganda only }\end{array}$ & $\begin{array}{l}\text { Undertaking production } \\
\text { expansion and will need the } \\
\text { COMESA Market. }\end{array}$ \\
\hline 16 & Mbeya Cement Ltd & 2005 & $\begin{array}{l}\text { Malawi, Burundi } \\
\text { and Rwanda }\end{array}$ & $\begin{array}{l}\text { Exports to Malawi \& Burundi } \\
\text { around US } \$ 3.5 \text { million a year. } \\
\text { But has high export potential if } \\
\text { duty free as it is now operating at } \\
\text { very small profit margin. Even } \\
\text { Northern Province of Zambia may } \\
\text { get cement form Mbeya factory. }\end{array}$ \\
\hline 17 & $\begin{array}{l}\text { Trishala Steel } \\
\text { Rolling Mills Ltd }\end{array}$ & 2005 & $\begin{array}{l}\text { Exports only to } \\
\text { Kenya and } \\
\text { Uganda under } \\
\text { ECA preferential } \\
\text { tariffs }\end{array}$ & $\begin{array}{l}\text { Undertaking expansion plans to } \\
\text { export to Rwanda, Burundi, DRC, } \\
\text { Malawi and Zambia. }\end{array}$ \\
\hline 18 & $\begin{array}{l}\text { Said } \\
\text { SalimBakhressa } \\
\text { Co. }\end{array}$ & & $\begin{array}{l}\text { Exports to Congo } \\
\text { (DR), Zambia, } \\
\text { Rwanda and } \\
\text { Malawi }\end{array}$ & $\begin{array}{l}\text { Still exporting some but has } \\
\text { potential to increase exports to all } \\
\text { these countries. }\end{array}$ \\
\hline 19 & $\begin{array}{l}\text { Soap \& Allied } \\
\text { Industries Ltd }\end{array}$ & 2005 & $\begin{array}{l}\text { Exporting to } \\
\text { Zambia, Malawi, } \\
\text { Congo (DR) etc }\end{array}$ & $\begin{array}{l}\text { Have high potential to increase } \\
\text { exports but there are many other } \\
\text { soap manufacturing companies } \\
\text { which can export to COMESA. }\end{array}$ \\
\hline 20 & OK Plast Ltd & 2005 & $\begin{array}{l}\text { Exports to } \\
\text { Malawi, } \\
\text { Rwanda, } \\
\text { Zimbabwe, } \\
\text { Zambia, Congo } \\
\text { (DR), Uganda, } \\
\text { Mozambique } \\
\end{array}$ & $\begin{array}{l}\text { Can export more to all these } \\
\text { countries and others. }\end{array}$ \\
\hline 21 & CMJ Karambaya & $\begin{array}{l}2005 \text { - June } \\
2006\end{array}$ & $\begin{array}{l}\text { Malawi, Burundi, } \\
\text { Rwanda, } \\
\text { Comoros, Congo } \\
\text { (DR), Zambia }\end{array}$ & $\begin{array}{l}\text { States that it can export if there is } \\
\text { external tariff Harmonisation and } \\
\text { free trade. }\end{array}$ \\
\hline 22 & $\begin{array}{l}\text { Jiemel Industries } \\
\text { Ltd }\end{array}$ & 2006 & $\begin{array}{l}\text { Kenya, Uganda, } \\
\text { Burundi, Malawi, } \\
\text { Zambia, Congo } \\
\text { (DR), Zimbabwe, } \\
\text { Southern Sudan. }\end{array}$ & $\begin{array}{l}\text { Exports some but has potential for } \\
\text { more exports if its products enjoy } \\
\text { duty free. }\end{array}$ \\
\hline 23 & $\begin{array}{l}\text { Matsushita Electric } \\
\text { (PANASONIC) } \\
\text { CO Ltd }\end{array}$ & & $\begin{array}{l}\text { Rwanda, } \\
\text { Burundi, } \\
\text { Congo } \\
\text { (DR), Malawi, } \\
\text { Comoros, } \\
\text { Madagascar } \\
\end{array}$ & $\begin{array}{l}\text { Used to export in the past and is } \\
\text { exporting a little now. It has } \\
\text { potential to export again. }\end{array}$ \\
\hline 24 & $\begin{array}{l}\text { Sumaria Group of } \\
\text { Tanzania Ltd }\end{array}$ & & $\begin{array}{l}\text { Malawi, } \\
\text { Zimbabwe, } \\
\text { Zambia, } \\
\text { Rwanda, } \\
\text { Burundi, } \\
\text { Comoros, } \\
\text { Congo(DR), } \\
\text { Madagascar, } \\
\text { Southern Sudan }\end{array}$ & $\begin{array}{l}\text { Some Sumaria Group Companies } \\
\text { such as Simba Plastics, Shelly's } \\
\text { Pharmaceuticals, SDL Ltd are } \\
\text { exporting and can increase } \\
\text { exports if COMESA Market is } \\
\text { opened. }\end{array}$ \\
\hline 25 & $\begin{array}{l}\text { Metal products Co. } \\
\text { Ltd }\end{array}$ & & $\begin{array}{l}\text { Malawi, } \\
\text { Zambia, } \\
\text { Rwanda, } \\
\text { Burundi, } \\
\text { Congo(DR) etc. }\end{array}$ & $\begin{array}{l}\text { Used to export and is still } \\
\text { exporting } \\
\text { some and has potential to export } \\
\text { more when free trade is made } \\
\text { available. }\end{array}$ \\
\hline 26 & $\begin{array}{l}\text { K-B Nair, the } \\
\text { Jubilee Insurance } \\
\text { of Tanzania }\end{array}$ & & $\begin{array}{l}\text { Exporting the } \\
\text { COMESA } \\
\text { Yellow Card } \\
\text { services to transit }\end{array}$ & $\begin{array}{l}\text { States that the sale of the Yellow } \\
\text { Card can increase greatly when } \\
\text { Tanzania is a member of } \\
\text { COMESA. }\end{array}$ \\
\hline
\end{tabular}




\begin{tabular}{|c|c|c|c|}
\hline & & $\begin{array}{l}\text { trucks from } \\
\text { COMESA } \\
\text { Countries e.g. } \\
\text { Malawi and } \\
\text { Zambia. }\end{array}$ & \\
\hline 27 & $\begin{array}{l}\text { A to Z Textiles } \\
\text { Mills Ltd }\end{array}$ & $\begin{array}{l}\text { Exports T. Shirts } \\
\text { and mosquito } \\
\text { nets to } \\
\text { COMESA } \\
\text { Countries }\end{array}$ & $\begin{array}{l}\text { Exports T. Shirts to South Africa. } \\
\text { But exports mosquito nets to all } \\
\text { COMESA Countries duty y free } \\
\text { under WHO campaign against } \\
\text { Malaria. It can export T-Shirts to } \\
\text { COMESA countries if duty free. }\end{array}$ \\
\hline 28 & $\begin{array}{l}\text { Tanzania } \\
\text { Pharmaceutical } \\
\text { Industries Ltd }\end{array}$ & $\begin{array}{l}\text { Congo (DR), } \\
\text { Malawi, Rwanda, } \\
\text { Burundi, Zambia, } \\
\text { Kenya Uganda, } \\
\text { Southern Sudan, } \\
\text { Madagascar, } \\
\text { Comoros, } \\
\text { Seychelles }\end{array}$ & $\begin{array}{l}\text { Company is undertaking state of } \\
\text { the art machinery installation and } \\
\text { production will need the } \\
\text { COMESA } \\
\text { Market. }\end{array}$ \\
\hline 29 & $\begin{array}{l}\text { Kibo Match Group } \\
\text { Ltd }\end{array}$ & $\begin{array}{l}\text { Rwanda, } \\
\text { Burundi, Malawi, } \\
\text { Congo(DR), } \\
\text { Southern Sudan, } \\
\text { Eritrea, } \\
\text { Comoros, } \\
\text { Madagascar } \\
\end{array}$ & $\begin{array}{l}\text { Exports to Kenya and Uganda } \\
\text { under EAC, and is capable of } \\
\text { exporting to COMESA to } \\
\text { COMESA } \\
\text { Countries. }\end{array}$ \\
\hline 30 & $\begin{array}{l}\text { Various cooking } \\
\text { oil companies e.g. } \\
\text { MURZAH OIL }\end{array}$ & $\begin{array}{l}\text { Malawi, Zambia, } \\
\text { Mozambique, } \\
\text { Rwanda, } \\
\text { Congo (DR), } \\
\text { Burundi, } \\
\text { Comoros, } \\
\text { Madagascar \& } \\
\text { Southern Sudan. }\end{array}$ & $\begin{array}{l}\text { Cooking oils is being exported to } \\
\text { many COMESA Countries by } \\
\text { various small \& medium scale } \\
\text { exporters even with duty paid but } \\
\text { Kenya exports more to Zambia, } \\
\text { Congo (DR) \& Rwanda, Burundi } \\
\text { due to duty free. }\end{array}$ \\
\hline
\end{tabular}

Source: Ng'andu, 2008 